\title{
UNDERSTANDING THE SOUTH AFRICAN FINANCIAL MARKETS: AN OVERVIEW OF THE REGULATORS
}

\author{
Lynette Swart
}

LLB (cum laude), LLM Student

Nelson Mandela Metropolitan University

Port Elizabeth

Vivienne A Lawack-Davids*

BJuris LLB LLM LLD

Professor, Executive Dean, Faculty of Law

Nelson Mandela Metropolitan University

Port Elizabeth

\section{SUMMARY}

This article examines the regulatory framework pertaining to the South African financial markets. The authors explain selected terminology and provide an overview of regulators in order to create an understanding of the regulatory environment to enhance transparency and add to the body of knowledge in financial markets law.

\section{$1 \quad$ INTRODUCTION}

The success of the financial market is dependent on certainty and financial stability of market participants. It is for this very reason that some of the Bank for International Settlements' Core Principles for Systemically Important Payment Systems ${ }^{1}$ relate to the requirement of a well-founded legal framework and transparency which would contribute towards certainty in the financial system. Certainty with regard to various aspects of the legal and regulatory environment is important during any time of crisis or upheaval

* The second author wishes to express her gratitude both the South African Reserve bank and Strate Limited for the valuable knowledge, skills and competencies gained during her employment at both institutions. Any mistakes, however, remain her own.

1 See eg, Core Principle I which states that "The system should have a well-founded legal basis under all relevant jurisdictions". Furthermore, see also Core Principle X which states that "The system's governance arrangements should be effective, accountable and transparent". The Bank for International Settlements published the Core Principles for Systemically Important Payment Systems in January 2001 (hereinafter "the Core Principles") http://www.bis.org/publ/cpss43.pdf?nof (accessed 2010-04-21). 
in the markets. It is evident that in the South African market there is a myriad of economic sources. However, there is a dearth of legal literature on issues pertaining to the financial markets. One of the Core Principles as it relates to central banks, provides for the fact that there should be transparency on the regulatory framework. ${ }^{2}$ It is through publication on these issues that an understanding of the financial markets will be created for lawyers who do not have practical experience in the financial sector and for future scholars as they embark on the journey of understanding the financial markets, thereby contributing to transparency and certainty on the legal framework. To this end, this article aims to give an overview of selected terminology and the regulatory framework pertaining to the financial market in South Africa.

\section{SELECTED FINANCIAL MARKET TERMINOLOGY}

Before one can examine the regulators, it is necessary to provide an overview of the role-players and financial instruments pertaining to the financial market. The following diagram of building blocks illustrates the concepts to be explained below:

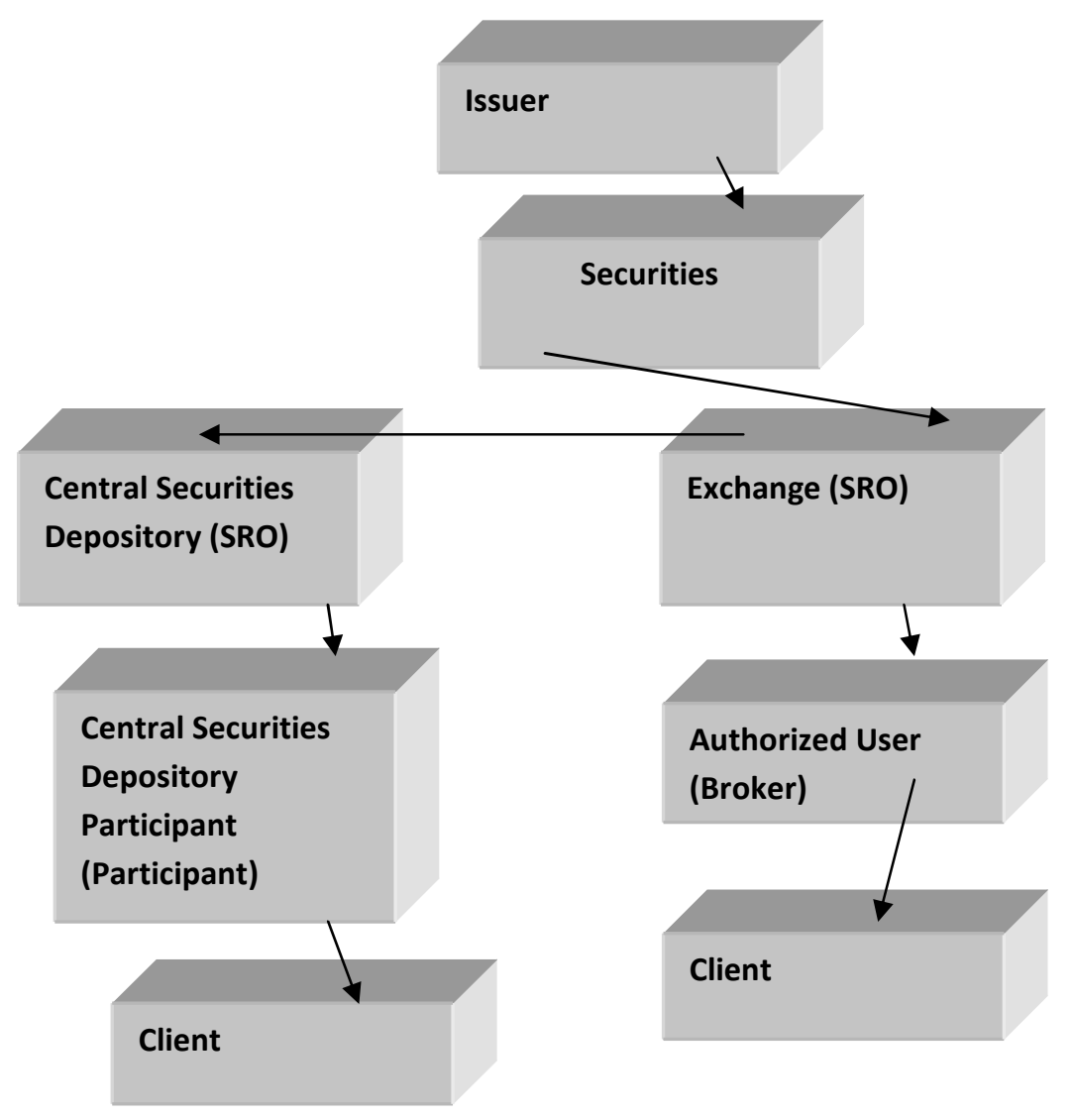

2 See Core Principle $X$ referred to in the previous footnote. 
The primary function of the financial market is to provide the place where "securities" can be traded between willing buyers and sellers. Section 1 of the Securities Services Act $^{3}$ defines securities as:

"shares, stocks and depository receipts in public companies and other equivalent equities, other than shares in a share block company as defined in the Share Blocks Control Act 59 of 1980; notes; derivative instruments; bonds; debentures; anticipatory interests in a collective investment scheme as defined in the Collective Investment Schemes Control Act 45 of 2002 and units or any other form of participation in a foreign collective investment scheme approved by the registrar of Collective Investment Schemes; units or any other form of participation in a collective investment scheme licensed or registered in a foreign country; instruments based on an index; the securities contemplated that are listed on an external exchange; and an instrument declared by the Registrar by notice in the Gazette to be a security for the purposes of the Companies Act and rights in the securities. The term 'securities' excludes money market instruments except for the purposes of Chapter IV of the SSA and any security specified by the registrar by notice in the Gazette."

A security enters the financial market by means of issuance in the primary market, after which it becomes tradable in the secondary market. ${ }^{4}$ The issuance of a security is conducted by an "issuer". An issuer refers to "an issuer of securities and, in Chapter IV of the SSA, includes an issuer of money market instrument". ${ }^{5}$

There are two ways in which the rights pertaining to securities may be symbolized. It can either be in certificated form (paper) or in uncertificated form. Certificated securities are "securities evidenced by a certificate or written instrument". ${ }^{6}$ Unlike certificated securities, uncertificated securities are "securities that are not evidenced by a certificate or written instrument and are transferable by entry without a written instrument".

Uncertificated securities are held and administered by a "central securities depository", ${ }^{8}$ which refers to a person who is licensed as a CSD in accordance with the SSA. ${ }^{9}$ In the CSD environment, one finds what is referred to as a "Participant". A Participant is "a person that holds in custody and administers securities or an interest in securities and that has been accepted in terms of section 34 by a central securities depository as a participant in that central securities depository". ${ }^{10}$ Such a Participant is commonly referred to as a "Central Securities Depository Participant". ${ }^{11}$ The terms Participant and CSDP are used interchangeably.

3 Securities Services Act 36 of 2004 (hereinafter "the SSA").

4 The primary market refers to that part of the capital market in which new securities are issued, whereas the secondary market refers to a market in which investors purchase securities subsequent to the original issuance in the primary market. Van Zyl, Botha, Skerrit and Goodspead Understanding South African Financial Markets 3ed (2009) 127.

See 1 of the SSA.

Ibid.

Ibid.

Central Securities Depository (hereinafter "a CSD").

See $s 32$ of the SSA.

See 1 of the SSA.

Central Securities Depository Participant (hereinafter "a CSDP").

12 In this dissertation the term "Participant" will be used. 
Securities can either be "unlisted securities" or "listed securities". Unlisted securities are securities not listed on an exchange and are traded over-thecounter. ${ }^{13}$ Listed securities are securities included in the list of securities kept by an "exchange". ${ }^{14}$ In other words, listed securities are issued and traded on an exchange. An exchange is

"a person who constitutes, maintains and provides an infrastructure:

(a) for bringing together buyers and sellers of securities;

(b) for matching the orders for securities of multiple buyers and sellers; and

(c) whereby a matched order for securities constitutes a transaction., ${ }^{15}$

An exchange may appoint what is referred to as an "authorized user". An authorized user is a person "authorized by an exchange in terms of the exchange rules to perform such securities services as the exchange rules may permit" and is commonly referred to as a "broker". ${ }^{16}$ The securities services performed by an authorized user refers to services provided in terms of the SSA in respect of "the buying and selling of securities; the custody and administration of securities; the management of securities by an authorized user; the clearing of transactions in listed securities; and the settlement of transactions in listed securities". ${ }^{17}$

In the financial market, reference is also made to the term "regulated person". A regulated person means a "self-regulatory organization or any other person who provides or who previously provided securities services". ${ }^{18}$ A "self-regulatory organization"19 is described as "an exchange or a central securities depository". ${ }^{20}$ Lastly, a "client" refers to "any person who uses the services of an authorized user or a Participant, as the case may be". ${ }^{21}$ The client is commonly the buyer or the seller of securities.

\section{THE REGULATORS}

\section{Introduction}

In every financial market system there is a need for regulators. Regulators supervise and regulate different aspects and activities within the financial market. South Africa does not have a single regulator, as different sections of the South African financial market are regulated by different regulators. Banks are regulated by the Banking Supervision Department ${ }^{22}$ of the South

13 Over-the-counter (hereinafter "OTC"). For a further discussion on the OTC market see par 2 51 below.

14 See $S 1$ of the SSA. These securities are kept by an exchange in accordance with $\mathrm{s} 12$ of the SSA.

15 Ibid.

16 Ibid.

Ibid.

Ibid.

Self-regulatory organization (hereinafter "SRO").

20 lbid. For the current SROs operating in terms for the SSA see par 231 below.

Ibid.

22 Bank Supervision Department (hereinafter "the BSD"). 
African Reserve Bank, ${ }^{23}$ while non-banking institutions are regulated by the Financial Services Board. ${ }^{24}$ Registration of companies takes place at the office of the Registrar of Companies, which forms part of the Department of Trade and Industry. ${ }^{25}$ Until recently, two licensed exchanges, namely the JSE Limited ${ }^{26}$ and the Bond Exchange of South Africa, ${ }^{27}$ operated as SROs in terms of the SSA. However, the JSE and BESA consolidated in 2009 and these exchanges now operate as a single exchange and accordingly, as a single SRO. ${ }^{28}$ The CSD, Share Transactions Totally Electronic Limited, ${ }^{29}$ also operates as a SRO in terms of the SSA. SROs regulate their own activities and those of authorized users and participants in terms of the provisions of the SSA. ${ }^{30}$

The South African financial market, thus, consists of the following regulators: the SARB, the FSB, the CSD and the JSE. The following paragraphs provide an overview of the establishments and organizational structures of these regulators.

\section{The South African Reserve Bank}

\section{History of the SARB}

The SARB is the central bank of South Africa. The founding of the SARB was necessitated by events before and immediately after World War I (1914 to 1918). ${ }^{31}$ Prior to the establishment of the SARB, all commercial banks were more or less on a par with one another and undertook much the same functions. ${ }^{32}$ One of the functions was the issuing of banknotes to the public. Unfortunately, no uniformity existed in legislation providing such issuance, except that the issuing banks were obliged to convert notes held by the public into gold when tendered at their branches. ${ }^{33}$

After the First World War the price of gold in the United Kingdom rose above its price in South Africa. As a result, profit could be made by converting banknotes into gold in South Africa and selling the gold in

23 South African Reserve Bank (hereinafter "the SARB").

24 Financial Services Board (hereinafter "the FSB").

25 Van Zyl et al 127.

26 JSE Limited (hereinafter "the JSE"). The Johannesburg Stock Exchange changed its name to JSE Securities Exchange South Africa in 2000 and again to JSE Limited in 2005. See Anonymous "JSE Limited" http://www.linkedin.com/companies/jse-limited (accessed 200912-21).

27 Bond Exchange of South Africa (hereinafter "the BESA").

28 The consolidation of the JSE and BESA is discussed in greater detail in par 2354 below.

29 Share Transactions Totally Electronic Limited (hereinafter "Strate"). The rebranding of STRATE is discussed in par 234 below.

30 Van Zyl et al 127.

31 South African Development Community Bankers "South African Reserve Bank" http://www.sadcbankers.org/SADC/SADC.nsf/LADV/B3796F16F143B8364225726E0049493 3/\$File/South+Africa.pdf (accessed 2009-05-20).

32 South African Reserve Bank "Factors leading to the founding of the South African Reserve Bank" http://www.icbs.co.za/internet/Publication.nsf/LADV/7EE59A82CC1F1E3742257337 004640FF/\$File/Fact+Sheet+6.pdf (accessed 2000-05-02).

33 South African Reserve Bank "About us - Background and Structure - Establishment of the South African Reserve Bank" http://www.reservebank.co.za/ (accessed 2009-05-17). 
London. This caused a very unfortunate situation for the South African commercial banks as they had to buy gold at a higher price in London for reimport into South Africa (to back their banknotes in issue) than the price at which they converted their banknotes for gold. To protect their financial viability, an appeal was made to the government to release commercial banks from the obligation to convert their banknotes into gold on demand. This led to the so-called Gold Conference of October 1919. ${ }^{34}$ The Conference recommended, inter alia, that a uniform banking act should replace the separate banking laws of the four provinces in force at that time. $^{35}$ Following the recommendations of the Conference, a Select Committee of Parliament recommended the establishment of a single and non-commercial institution to assume responsibility for the issuing of banknotes and for taking over the gold held by commercial banks. ${ }^{36}$ Parliament accepted this recommendation and in December 1920 promulgated the Currency and Bank $\mathrm{Act}^{37}$ which provided for the establishment of a central bank, the SARB. The first Governor of the SARB was appointed with effect from 17 December 1920. Six months after the promulgation of the Currency and Banking Act the SARB opened its doors for business for the first time on 30 June $1921 .^{38}$ The Currency and Banking Act was amended from time to time and re-enacted in the form of the South African Reserve Bank Act of $1944 .{ }^{39}$ This 1944 Act was repealed and substituted by the South African Reserve Bank Act of $1989 .{ }^{40}$

Sections 223 to 225 of the Constitution ${ }^{41}$ the SARB Act and the SARB regulations present the structure of the SARB's business and describe the functions and also the actions that the SARB may take in fulfilling its purpose. ${ }^{42}$ Section 223 of the Constitution provides for the establishment of the SARB as the central bank of South Africa. Section 224(1) of the Constitution and section 3 of the SARB Act provide that the primary objective of the SARB is to protect the value of currency of the Republic in the interest of balanced and sustainable economic growth in the Republic. ${ }^{43}$ Section 224(2) states that "[t]he South African Reserve Bank, in pursuit of its primary object, must perform its functions independently and without fear, favour or prejudice, but there must be regular consultation between the Bank and the Cabinet member responsible for national financial matters". Section 225 states that the powers and functions of the SARB are those customarily

34 Ibid.

35 South African Reserve Bank "Factors leading to the founding of the South African Reserve Bank" http://www.icbs.co.za/internet/Publication.nsf/LADV/7EE59A82CC1F1E3742257337 004640FF/\$File/Fact+Sheet+6.pdf (accessed 2009-05-02).

36 South African Reserve Bank "About us - Background and Structure - Establishment of the South African Reserve Bank" http://www.reservebank.co.za/ (accessed 2009-05-17).

3731 of 1920.

38 South African Development Community Bankers "South African Reserve Bank" http://www.sadcbankers.org/SADC/SADC.nsf/LADV/B3796F16F143B8364225726E0049493 3/\$File/South+Africa.pdf (accessed 2009-05-20).

39 Act 29 of 1994.

40 Act 90 of 1989 (hereinafter "the SARB Act").

41 The Constitution of the Republic of South Africa, 1996 (hereinafter "the Constitution").

42 Wille, Keetse, Matthee, Moolman and Muwanula Principles of Financial Law (2007) 152.

43 S 3 of the SARB Act and S 224(1) of the Constitution. 
exercised and performed by central banks, which powers and functions must be determined by an Act of Parliament (the Act referred to is the SARB Act) and must be exercised or performed subject to the conditions prescribed in terms of that Act.

\section{The role of the SARB}

The SARB plays multiple roles in the financial market and includes the following. Firstly, the SARB, as lead regulator of banks in South Africa, is responsible for bank regulation and supervision. This function is performed by issuing banking licences to banking institutions and monitoring their activities in terms of either the Banks Act ${ }^{44}$ or the Mutual Banks Act. ${ }^{45}$

Secondly, Section 10(c) (i) of the SARB Act states that the SARB may "perform such functions, implement such rules and procedures and, in general, take such steps as may be necessary to establish, conduct, monitor, regulate and supervise payment, clearing or settlement systems." The National Payment System Act ${ }^{46}$ enables the SARB to perform these functions as contemplated and the authority to perform these functions vests in the National Payment System Department ${ }^{47}$ of the SARB. ${ }^{48}$

Finally, according to section 10 of the SARB Act, ${ }^{49}$ the SARB may also exercise the following powers relating to the financial market:

"(g) Buy, sell, discount or re-discount bills of exchange drawn or promissory notes issued for commercial, industrial or agricultural purposes, or

4494 of 1990 (hereinafter "the Banks Act").

45124 of 1993 (hereinafter "the Mutual Banks Act"). South African Reserve Bank "SARB activities - Bank Supervision" http://www.reservebank.co.za/ (accessed 2009-05-17). See also par 2323 below. In terms of the SSA, a "bank" is defined as "a bank as defined in the Banks Act and a mutual bank as defined in the Mutual Banks Act". According to the Banks Act, a "bank" is defined as "a public company registered in terms of this Act and the Mutual Banks Act defines a "mutual bank" as "a juristic person -

"(a) the members of which -

(i) qualify as such by virtue of their being shareholders of that juristic person: and

(ii) are entitled to participate in the exercise of control in a general meeting of that juristic person; and

(b) that is provisionally or finally registered as a mutual bank in terms of this Act."

It is important to note the definition in the Banks Act of a "branch" which provides for foreign institutions conducting business of a bank in SA to be regulated in terms of the Act. The Act defines a "branch" as "an institution that is not a public company as contemplated in s 11(1), but by means of which a foreign institution conducts the business of a bank in the Republic under the authorization referred to in s 18A". See Annexure B for the list of the registered banks currently in South Africa.

4678 of 1998 (hereinafter "the NPS Act").

47 National Payment System (hereinafter "the NPSD").

48 South African Reserve Bank "Overview of the South African National Payment System" http://www.reservebank.co.za/internet/Publication.nsf/LADV/AD4E4B492E69831342257501 004AABAE/\$File/OverviewofNPS1.pdf (accessed 2009-08-26). See also South African Reserve Bank "The National Payment System in South Africa 1995 to 2005" http://www.reservebank.co.za/internet/Publication.nsf/LADV/5ABB40C9AD3DD0F5422572B C0033170B/\$File/NPS95to05.pdf (accessed 2009-07-25). For a further discussion of the NPS Department see par 2323 below.

$49 \mathrm{~S} 10(\mathrm{~g})-(\mathrm{m})$ of the SARB Act. 
exchequer bills of the Government of the Republic or of the government of any other country, or securities of a local authority in the Republic;

(h) buy, sell or deal in financial instruments and, in accordance with the provisions of any law regulating the safe deposit of securities, hold such financial instruments in safe custody, or cause such financial instruments to be held in safe custody, for other persons;

(i) issue its own interest-bearing securities for purposes of monetary policy and buy, sell, discount or re-discount, or grant loans or advances against, such securities;

(j) subject to the provisions of section 13(a) and (b), enter into repurchase agreements with any institution in respect of interest-bearing securities or such other securities as the Bank may determine;

(k) buy, sell, or deal in precious metals and hold in safe custody for other persons gold, securities or other articles of value;

(I) buy and sell foreign currencies; and

(m) buy, sell, accept or deal in special drawing rights."

The SARB not only fulfils various roles in the financial market, but also in the economy of South Africa as a whole. These roles include: ${ }^{50}$

- The issuance of bank notes and coins; ${ }^{51}$

- it acts as the banker to the government, the custodian of the country's official gold and other foreign reserves as well as the government's funding agent;

- it also formulates and implements monetary and exchange-rate policy in cooperation with the National Treasury;

- it monitors and promotes the stability of the financial system; ${ }^{52}$

- it administers exchange control;

- it compiles and publishes macro-economic data and, more importantly; and

- it acts as lendor of last resort for domestically registered banks. ${ }^{53}$

\section{The Organizational Structure of the SARB}

The SARB is divided into various departments, each with its own designated duties and functions to ensure effective supervision and regulation. ${ }^{54}$ For purposes of this dissertation, the BSD, the Financial Markets Department ${ }^{55}$ and the NPSD are of importance.

50 South African Development Community Bankers "South African Reserve Bank" http://www.sadcbankers.org/SADC/SADC.nsf/LADV/B3796F16F143B8364225726E0049493 3/\$File/South+Africa.pdf (accessed 2009-05-20).

51 See $\mathrm{s} 10$ (1)(a) and (b) of the SARB Act.

52 This role is not stated in the SARB Act as such, but it is communicated by the SARB as part of its functions.

53 South African Reserve Bank "SARB activities - Bank Supervision - Bank Supervision circulars, directives and guidance notes - Banks Act circulars" http://www.reservebank. co.za/ (accessed 2010-04-19).

54 See Annexure $C$ for a diagram on the Organizational Structure of the SARB.

55 Financial Markets Department (hereinafter "the FMD"). 
The BSD is responsible for bank regulation and supervision and strives to achieve a sound, efficient banking system in the interest of the depositors of banks as well as the economy. ${ }^{56}$

The FMD of the SARB performs international banking and international treasury services, implements the Reserve Bank's interest-rate policy, ${ }^{57}$ acts as funding agent of the government, facilitates the effective functioning of the domestic financial markets and manages the SARB's gold and foreign exchange reserves. ${ }^{58}$

The NPSD of the SARB oversees the safety and soundness of the National Payment System ${ }^{59}$ and implements risk-reduction procedures in the payment system to reduce systemic risk. ${ }^{60}$ The SARB describes the function of the NPS as follow: ${ }^{61}$

"The NPS does not only entail payments made between banks, but encompasses the total payment process. This includes all the systems, mechanisms, institutions, agreements, procedures, rules and laws that come into play from the moment an end-user, using a payment instrument, issues an instruction to pay another person or a business, through to the final interbank settlement of the transaction in the books of the central bank. The NPS therefore enables transacting parties to exchange value to conduct business efficiently."

The NPS of the SARB operates the Reserve Bank Settlement System, ${ }^{62}$ a the real-time electronic-settlement system called the South African Multiple Option Settlement ${ }^{63}$ (SAMOS) system. ${ }^{64}$

\section{The financial-services board}

\section{The establishment of the FSB}

The FSB was established as a separate government agency in terms of the Financial Services Board Act ${ }^{65}$ and became operational on 1 April $1991 .{ }^{66}$

56 South African Reserve Bank "SARB activities - Bank Supervision" http://www.reservebank. co.za/ (accessed 2009-05-17).

57 For a discussion on this role of the SARB, see par 2625 below.

58 South African Reserve Bank "SARB Activities - Financial Markets" http://www.reservebank. co.za/ (accessed 2009-08-24).

59 National Payment System (hereinafter "the NPS").

60 South African Reserve Bank "SARB Activities - Payment \& Settlement Systems" http://www.reservebank.co.za/ (accessed 2009-08-26). In terms of s of the SSA "systemic risk" means "the danger of a failure or disruption of the Republic's financial system as a whole".

61 South African Reserve Bank "Overview of the South African National Payment System" http://www.reservebank.co.za/internet/Publication.nsf/LADV/AD4E4B492E69831342257501 004AABAE/\$File/OverviewofNPS1.pdf (accessed 2009-08-26); and South African Reserve Bank Financial Stability Review 200839 and 40. See also South African Reserve Bank "The National Payment System Framework and Strategy Vision 2010" http://www.pasa. org.za/pdf/vision2010.pdf (accessed 2009-10-13).

62 The term "Reserve Bank Settlement System" is used in the National Payment System Act 78 of 1998.

63 South African Multiple Option Settlement (hereinafter "SAMOS").

64 Ibid. See also par 52 below.

6597 of 1990 (hereinafter "the FSB Act"). 
The FSB oversees the South African Non-Banking Financial Services Industry in the public interest and sets the regulatory framework as well as the minimum standards and practices for market participants. ${ }^{67}$

According to the FSB Act the functions of the FSB are: ${ }^{68}$

- "to supervise compliance with laws regulating financial institutions ${ }^{69}$ and the provision of financial services;

66 Van Zyl et al 128.

67 Financial-Services Board "Welcome to the FSB" http://www.fsb.co.za/ (accessed 2009-1220) and Bond Exchange of South Africa "Market Structure" http://www.bondexchange. co.za/besa/view/besa/en/page109 (accessed 2009-05-04). In terms of the s 35A(1) of the Insolvency Act 24 of 1936 (hereinafter "the Insolvency Act") a market participant means an authorized user, a participant, a client or a settling party as defined in S 1 of the SSA or any other party to a transaction. The terms authorized user, participant and client are defined in par 22 above. In terms of $\mathrm{S} 1$ of the SSA a settling party means a buyer or seller of listed securities who settles a transaction or any person appointed in terms of exchange rules by such buyer or seller to settle a transaction on behalf of such buyer or seller.

$68 \mathrm{~S} 3$ of the FSB Act.

69 S 1 of the FSB Act defines a "financial institution" as "(a) ...

(i) any pension fund organization registered in terms of the Pension Funds Act, 1956 (Act No. 24 of 1956), or any person referred to in section 13B of that Act administering the investments of such a pension fund or the disposition of benefits provided for in the rules of such a pension fund;

(ii) any friendly society registered in terms of the Friendly Societies Act, 1956 (Act No. 25 of 1956), or any person in charge of the management of the affairs of such a society;

(iii) a collective investment scheme as defined in section 1 of the Collective Investment Schemes Control Act, 2002. a manager, trustee, custodian or nominee company registered or approved in terms of that Act, and an authorized agent of such a manager;

[Subpara. (iii) substituted by s 117 of Act 45/2002 and s 19 of Act 22/2008]

(iv) $\ldots$

[Subpara. (iv) deleted by s 19 of Act 22/2008]

(v) any 'exchange', 'authorized user', 'stock -broker', 'settling party', 'clearing house', 'central-securities depository', 'participant' or 'nominee' as defined in section 1 of the Securities Services Act, 2004;

[Subpara. (v) substituted by s 117 of Act 36/2004]

(vi) $\ldots$

[Subpara. (vi) deleted by s 117 of Act 36/2004]

(vii) any 'long-term insurer' as defined in section 1(1) of the Long-term Insurance Act, 1998 (Act No. 52 of 1998). and any 'short-term insurer' as defined in section 1(1) of the Short-term Insurance Act 1998 (Act No. 53 of 1998);

[Subpara. (vii) substituted by s 19 of Act 22/2008]

(viii) any 'independent intermediary' or representative as defined in -

(aa) section 1(1) of the Short-term Insurance Act, 1998;

(bb) regulation 3.1 of the Regulations under the Long-term Insurance Act, 1998; or

[Subpara. (viii) substituted by $s 19$ of Act 22/2008]

(ix) any 'Lloyd's underwriter' as defined in section 1(1) of the Short-term Insurance Act, 1998 , and referred to in section 56 of that Act;

[Subpara. (ix) substituted by $s 19$ of Act 22/2008]

$(x)$ any person rendering or who is to render services contemplated in section $23 \mathrm{~A}(1)$ of the Insurance Act, 1943;

(xi) $\ldots$ 
- to advise the Minister on matters concerning financial institutions and financial services, either of its own accord or at the request of the Minister; and

- to promote programmes and initiatives by financial institutions and bodies representing the financial services industry to inform and educate users and potential users of financial products and services."

The FSB supervises various non-banking financial institutions through the respective Acts enacted for this purpose. The Acts administered by the FSB include:

- FSB Act $^{70}$

- the SSA; ${ }^{71}$

- Collective Investment Schemes Control Act; ${ }^{72}$

- Financial Advisory and Intermediary Services Act; ${ }^{73}$

- Financial Institutions (Protection of Funds) Act; ${ }^{74}$

- Financial Supervision of the Road Accident Fund Act; ${ }^{75}$

- Inspection of Financial Institutions Act; ${ }^{76}$

- Friendly Societies Act; ${ }^{77}$

- Long-term Insurance Act, ${ }^{78}$

- Pension Fund Act, ${ }^{79}$

- Short-term Insurance Act: ${ }^{80}$ and

[Subpara. (xi) deleted by s 117 of Act 36/2004]

(xii) any authorized financial services provider' or 'representative' as defined in section 1 (1) of the Financial Advisory and Intermediary Services Act, 2001;

[Subpara. (xii) added by s 45 of Act 37/2002]

(b) $\ldots$

(i) a bank as defined in section 1(1) of the Banks Act, 1990 (Act No. 94 of 1990), a mutual bank as defined in section 1(1) of the Mutual Banks Act, 1993 (Act No. 124 of 1993), or a co-operative bank as defined in section 1(1) of the Co-operative Banks Act, 2007 (Act No. 40 of 2007), which deals with trust property as a regular feature of its business; or

[Subpara. (i) substituted by s 19 of Act 22/2008]

(ii) any other person who or which deals with trust property as a regular feature of his, her or its business, but who is not registered, licensed, recognized, approved or otherwise authorized to deal so in terms of any Act, other than the Companies Act, 1973 (Act No. 61 of 1973), the Close Corporations Act, 1984 (Act No. 69 of 1984), 97 of 1990. and the Trust Property Control Act, 1988 (Act No. 57 of 1988)."

71 Act 36 of 2004

7245 of 2002.

37 of 2002 (hereinafter "the FAIS Act").

28 of 2001.

8 of 1993.

80 of 1998

25 of 1956

52 of 1998

24 of 1956.

80 53 of 1998 . 
- Supervision of the Financial Institutions Rationalization Act. ${ }^{81}$

\section{The Organizational Structure of the FSB}

The FSB consists of various divisions and departments, designed to regulate, supervise and perform such functions as assigned to the $\mathrm{FSB} .{ }^{82}$ These divisions and departments operate in terms of the above-mentioned Acts $^{83}$ and consist of the following:

- Financial Advisory and Intermediary Services Division;

- Capital Market Department; Inspectorate Department;

- Insurance Department; the Collective Investment Schemes Department;

- Retirement Funds and Friendly Societies Department; and

- The Directorate of Market Abuse.

For the purposes of this dissertation the Financial Advisory and Intermediary Services Division ${ }^{84}$ and the Capital Markets Department ${ }^{85}$ are of importance.

The FAIS Division is responsible for the regulation and supervision of Financial Service Providers and is regulated by the FAIS Act. ${ }^{86}$ The FAIS Act defines a "financial-service provider" as: ${ }^{87}$

"any person, ${ }^{88}$ other than a representative, ${ }^{89}$ who as a regular feature of the business of such person -

(a) furnishes advice, ${ }^{90}$ or

32 of 1996.

82 See Annexure $D$ for a diagram on the Organizational Structure of the FSB.

83 See par 2331 above.

84 Financial Advisory and Intermediaries Department (hereinafter "the FAIS Division").

85 Capital Markets Department (hereinafter "the CMD").

86 Financial Services Board "About the Financial Advisory and Intermediaries Services Division" http://www.fsb.co.za/ (accessed 2009-08-23).

87 See $\mathrm{s} 1$ of the FAIS Act.

88 In terms of $\mathrm{s} 1$ of the FAIS Act, the term "person" refers to "any natural person, partnership or trust, and includes -

(a) any organ of state as defined in section 239 of the Constitution of the Republic of South Africa, 1996;

(b) any company incorporated or registered as such under any law; and

(c) any body of persons corporate or incorporate."

89 In terms of $\mathrm{s} 1$ of the FAIS Act, the term "representative" is defined as: "any person employed or mandated by such first-mentioned person, who renders a financial service to a client for or on behalf of financial-service provider, on terms of conditions of employment or any other mandate, but excludes a person rendering clerical, technical, administrative, legal, accounting or other service in a subsidiary or subordinate capacity, which service -

(a) does not require judgment on the part of the latter person; or

(b) does not lead a client or any specific transaction on respect of a financial product in response to general enquiries."

90 In terms of $\mathbf{S} 1$ of the FAIS Act the term "advice" means: "subject to subsection (3)(a), any recommendation, guidance or proposal of a financial nature furnished, by any means or medium, to any client or group of clients -

(a) in respect of the purchase of any financial product; or 
(b) furnishes advice and renders any intermediary service, ${ }^{91}$ or

(c) renders an intermediary service" (authors' own italics).

The FAIS Division is subdivided into three departments, namely the Registration Department, ${ }^{92}$ the Supervision Department ${ }^{93}$ and the Enforcement Department. ${ }^{94}$

The CMD regulates the capital markets in South Africa in terms of the SSA. ${ }^{95}$ It was the CMD, together with a drafting team consisting of industry representatives and experts, who designed the SSA in conjunction with the National Treasury. ${ }^{96}$ The mission of the CMD is "to ensure sound, efficient and fair capital markets and related services for the trade of securities, including appropriate mechanisms for investor protection." 97 The CMD also ensures compliance with international regulatory standards by participating

(b) in respect of the investment in any financial product; or

(c) on the conclusion of any other transaction, including a loan or cession, aimed at the incurring of any liability or the acquisition of any right or benefit in respect of any financial product; or

(d) on the variation of any term or condition applying to a financial product, on the replacement of any such a product, or on the termination of any purchase of or investment in any such product, and irrespective of whether or not such advice -

(i) is furnished in the course of or incidental to financial planning in connection with the affairs of the client; or

(ii) results in any purchase, investment, transaction, variation, replacement or termination, as the case may be being effected."

91 In terms of s 1 of the FAIS Act "an intermediary service" means: "subject to subsection (3)(b), any act other that the furnishing of advice, performed by a person for or on behalf of a client or product supplier -

(a) the result of which is that a client may enter into, offers to enter into or enters into any transaction in respect of a financial product with a product supplier; or

(b) with a view to -

(i) buying, selling or otherwise dealing in (whether on a discretionary or nondiscretionary basis), managing, administering, keeping in safe custody, maintaining or servicing a financial product purchased by a client from a product supplier of in which the client has invested;

(ii) collecting or accounting for premiums or other moneys payable by the client to a product supplier in respect of a financial product; or

(iii) receiving, submitting or processing the claims of a client against a product supplier."

92 The Registration Department is responsible for the processing of licence applications, approval of compliance officers, profile changes and levies. See Financial Services Board "Service level commitment by the Registrar of financial-services providers" ftp://ftp.fsb.co.za/ public/FAIS_SLC_2008-12-04.pdf (accessed 2009-12-20).

93 The Supervision Department is responsible for the supervision of authorized Financial Services Providers by way of on-site visits, analyses-compliance reports and statutory returns. See Financial Services Board "Service-level commitment by the Registrar of financial-services providers" ftp://ftp.fsb.co.za/public/FAIS_SLC_2008-12-04.pdf (accessed 2009-12-20).

94 The Enforcement Department is responsible for investigations of complaints and also for taking regulatory action against authorized providers in the form of suspension or withdrawal of licenses. See Financial Services Board "Service level commitment by the Registrar of financial-services providers" ftp://ftp.fsb.co.za/public/FAIS_SLC 2008-12-04.pdf (accessed 2009-12-20).

95 Van Zyl et al 130

96 Ibid.

97 Financial Services Board "Capital Markets Department" http://www.fsb.co.za/ (accessed 2009-08-23). 
in the International Organization of Securities Commissions. ${ }^{98}$ IOSCO has, inter alia, laid down 30 Objectives and Principles of Securities Regulation. South Africa, through the CMD, intends to comply with these IOSCO 30 Objectives and Principles. ${ }^{99}$

The CMD provides the secretariat of the Financial Markets Advisory Board, ${ }^{100}$ which was established in terms of the (now repealed) Financial Markets Control Act. ${ }^{101}$ The purpose of the FMAB is to, on its own initiative and at the request of the Minister or the registrar, investigate and report or advise on, administrative and technical matters concerning regulated persons or the provision of securities services. ${ }^{102}$

\section{Central-Securities Depository}

The introduction of the Johannesburg Equities Trading ${ }^{103}$ system in 1995 highlighted certain deficiencies in the JSE's paper-based settlement system. As a result of the JET system, shares were no longer traded on a trading floor and accordingly, the number of daily trades increased hugely. Backoffice support services were incapable of handling these increases efficiently and a transition into an effective electronic-settlement system was needed. ${ }^{104}$

Consequently, a CSD known as Shares Transactions Totally Electronic (STRATE) was established by the JSE, in collaboration with South Africa's four largest commercial banks, in $1999 .{ }^{105}$ In August 2003, STRATE Limited was formed by the merger of STRATE, the clearing and settlement house of BESA, UNEXcor, and the Central Depository Limited. ${ }^{106}$ STRATE Limited was rebranded in 2007 as Strate Limited. This article uses the rebranded name.

Strate handles the settlement ${ }^{107}$ of equities, warrants and bonds for the JSE and is in the process of adding the electronic settlement of moneymarket securities to its portfolio of services. The main purpose of Strate is to mitigate risk, bring efficiencies to the market and improve SA's profile as an

98 International Organization of Securities Commissions (hereinafter "IOSCO"). For a further discussion on IOSCO see par 2481 below.

99 Van Zyl et al 131.

${ }^{100}$ Financial Markets Advisory Board (hereinafter the "FMAB"). It has to be noted that the FMAB's existence has been carried over by the SSA.

10155 of 1989 (hereinafter "the FMCA").

102 S 6(7) of the SSA. It has to be noted how broad the ambit of the FMAB is, as securities are very broad as defined in the SSA. See the definition of securities services in par 22 above.

103 Johannesburg Equities Trading (hereinafter "JET"). JET was the automated trading system of the JSE at the time. This system was subsequently replaced by the London Exchange's SETS System in 2002 and again by TradElect in 2007. See par 2352 below.

104 Strate Limited "The Need for Strate" http://www.strate.co.za/Strate/AboutUs/General/ TheNeedforStrate/ (accessed 2009-08-26).

105 David, Cassim, Mongalo, Butler, Loubser, Coetzee and Burdette Companies and other Business Structures in South Africa (2009) 264.

${ }^{106}$ Van Zyl et al 217.

107 The term "settlement" and the settlement process in South Africa are discussed in par 31 and 32 below. 
investment destination. ${ }^{108}$ Strate is regulated by the SSA and in accordance with the SSA, issues its own CSD Rules and Directives. ${ }^{109}$ Strate is a public unlisted company with dematerialized assets under custody in excess of 5.0 trillion (ZAR). ${ }^{1}$

In terms of the SSA, ${ }^{111}$ a CSD must "have made arrangements for the proper supervision of compliance by Participants with the depository rules". Consequently, the controlling body ${ }^{112}$ of Strate has delegated its supervisory obligations to the Strate Regulatory and Supervisory Committee. The committee assists the controlling body in discharging its regulatory and supervisory obligations in terms of the SSA and the Rules.

\section{JSE Limited}

\section{Introduction}

During 2009 BESA became a wholly-owned subsidiary of the JSE. ${ }^{114}$ Accordingly, the JSE is now the single exchange in South Africa. However, a discussion on the establishment and the development of both the JSE and BESA is still necessary as it provides a background to the corporate identity of the JSE.

\section{JSE Limited}

The JSE was established in 1887, following the discovery of gold on the Witwatersrand in 1886. This discovery resulted in the rapid formation of mining houses and financial companies, and also the lack of adequate and efficient communication systems. Consequently, a stock exchange in Johannesburg was needed and the JSE was established. ${ }^{115}$ The JSE joined the World Federation of Exchanges in 1963. ${ }^{11}$

The JSE was deregulated through the introduction of limited liability corporate and foreign membership in 1995 and the JSE's open outcry-

108 Strate Limited http://www.strate.co.za/Strate (accessed 2009-06-25).

109 Strate also publishes Practice Notes. However, these Practices Notes are not referred to or required by the SSA and are merely utilized for interpretative purposes. For a discussion on the CSD Rules and Directives see par 2523 below.

110 Strate Limited at http://www.strate.co.za/Strate (accessed 2009-06-25).

111 S 31(1)(b) of the SSA.

112 The controlling body of Strate consists of the board of directors of Strate.

113 Strate Limited "Strate Regulatory and Supervisory Committee" http://www.strate.co.za/ Strate/Supervision/Regulatory/STRATERegulatorySupervisoryCommittee/ (accessed 200908-26). See Annexure E for a diagram on the Regulatory and Supervisory pyramids of Strate. The diagrams illustrate the regulation and supervision of equities and bonds respectively. To date, the regulatory and supervision pyramid for money-market instruments has not yet been published.

114 This consolidation is discussed in greater detail in par 2354 below.

115 PSG Online "The Historical Development Of The JSE" http://www.psg-online.co.za/wiki/ (S(mvqau055u1myt455irqa0efp))/-Chapter2HistoricalDevelopmentOfTheJse.ashx (accessed 2009-12-21).

116 David et al 264; and JSE Limited "History of the JSE" http://www.jse.co.za/About-Us/ History-Of-The-JSE.aspx (accessed 2009-12-21). 
trading floor was closed and replaced by an automated trading system, known as the JET system, ${ }^{117}$ in 1996. The JSE introduced the Securities Exchange News Service, ${ }^{118}$ to provide for the early and wide dissemination of all information that may have an effect on the prices of securities that trade on the JSE, in 1997.

The JSE played a leading role as part of the establishment of Strate in $1999^{120}$ and all the JSE-listed securities were successfully dematerialized ${ }^{121}$ and migrated to Strate in 2002. The JSE acquired the South African Futures Exchange $^{122}$ in 2001 and consequently became the leader in both equities and equity- and agricultural-derivatives trading in South African. ${ }^{12}$

The JSE JET system was replaced by the London Stock Exchange's SETS system, hosted and operated from the London Stock Exchange in London, in 2002. This system was called "JSE SETS". Following this system, the JSE introduced another system, called InfoWiz, in that same year. The purpose of InfoWiz is to provide a world-class information dissemination system and substantially improve the distribution of real-time equities-market information. During this year, the JSE also launched a freefloat indexing system in conjunction with FTSE, namely the FTSE/JSE African Index Series to replace the then existing indices. ${ }^{124}$

The JSE launched Alternative Exchange (AltX), which focuses on good quality small and medium-sized high-growth companies, in 2003 and the Socially Responsible Investment (SRI) Index, which measures compliance by companies with triple-bottom line criteria around economic, environmental and social sustainability, in 2004. The JSE launched Yield- $X^{125}$ in 2005, followed by the commencement of over-the-counter trading in JSE shares with settlement of the trades occurring through Strate in the same year. The JSE demutualized and was incorporated in South Africa as JSE Limited, a public-unlisted company, in 2005 and listed on the JSE Main Board in $2006 .{ }^{126}$ The JSE SETS system was subsequently replaced by the TradElect system in $2007 .^{127}$

117 See fn 112 above.

118 Securities Exchange News Service (hereinafter "the SENS").

119 David et al 264; and JSE Limited "History of the JSE" http://www.jse.co.za/About-Us/HistoryOf-The-JSE.aspx (accessed 2009-12-21).

120 As noted in par 234 above.

121 Dematerialisation means "the process of converting certificated securities into uncertificated securities". See Strate Limited "Glossary D" http://www.strate.co.za/Strate/Glossary/D.htm (accessed 2009-12-21).

122 South African Futures Exchange (hereinafter "the SAFEX").

123 David et al 264; and JSE Limited "History of the JSE" http://www.jse.co.za/About-Us/HistoryOf-The-JSE.aspx (accessed 2009-12-21).

124 Ibid.

125 See par 2724 below.

126 David et al 264; and JSE Limited "History of the JSE" http://www.jse.co.za/About-Us/HistoryOf-The-JSE.aspx (accessed 2009-12-21).

127 David et al 264; and Beduli, W "Workings of the JSE" http://209.85.229.132/search?q= cache:Dy5R_ftlpn4J:www.joasa.org.za/aricles/JSE\%2520slides.ppt+JSE+tradElect+replace $\mathrm{s}+\mathrm{JSE}+\mathrm{SETS} \& \mathrm{~cd}=3 \& \mathrm{hl}=\mathrm{en} \& \mathrm{ct}=\mathrm{clnk} \& \mathrm{gl}=\mathrm{za}$ (accessed 2009-12-21). 
It is evident from the above that, for the past almost 120 years, the JSE evolved from a traditional trading-floor based equities-trading market to a modern securities exchange providing fully electronic trading, clearing and settlement in equities, financial and agricultural derivatives and other associated instruments. ${ }^{128}$ The main function of the JSE is to facilitate the raising of capital by borrowers in the primary market and trading of securities in the secondary market by lenders and investors. ${ }^{129}$

The JSE's market turnover was R6 $534027 \quad 334$ and its market capitalization R7 407184350 at the end of 2007. ${ }^{130}$ According to the latest figures at 31 June 2009, the JSE's market turnover was valued at 30641 US Dollars, placing it $21^{\text {st }}$ on the World League and its market capitalization of 608046 placed it $19^{\text {th }} .{ }^{131}$ The JSE is regulated by the SSA and in accordance with the SSA issues its own Rules, Directives and Guarantee Fund Rules.

\section{Bond Exchange of South Africa (BESA)}

The establishment of BESA dates back to the 1980's when the "Stals/Jacobs Report" recommended tight control via regulation in the financial market under the umbrella of the then FMCA. ${ }^{132}$ The authorities, however, were of the opinion that self-regulation by market participants were more acceptable and desirable than imposed regulation. In light of this view, the majority of the bond-market participants formed a voluntary association, the Bond Market Association in 1989. ${ }^{133}$ This Bond Market Association was formally licensed as an exchange in terms of the SSA in 1996, as BESA. ${ }^{134}$ BESA is responsible for operating and regulating the debt-securities and interest-rate derivatives markets in South Africa. ${ }^{13}$

BESA established a Bond Traders' Association ${ }^{136}$ to represent and promote the interests of the BTA members in their relations with the bond market's regulatory authority, BESA, and to promote good relations between its members in 2002. ${ }^{137}$ BESA also formed a Derivatives Traders'

128 JSE Limited "Company Overview" http://www.jse.co.za/About-Us/Overview-of-the-JSE.aspx (accessed 2009-06-30)

129 Van Zyl et al 322.

130 JSE Limited "JSE's share performance during 2007" http://www.onlinewebstudio.co.za/ jse_ar07/si_perform.html (accessed 2009-08-31).

131 JSE Limited "JSE market highlights" http://209.85.229.132/search?q=cache:A0X_gl1xe KQJ:phx.corporate-ir.net/External.File\%3Fitem\%3DUGFyZW50SUQ9MTMwOTI8Q2hpbG RJRD0tMXxUeXBIPTM\%3D\%26t\%3D1+JSE+july+turnover+2009\&cd=6\&hl=en\&ct=clnk (accessed 2009-08-31).

132 Strate Limited Bonds Handbook Version 2.0 (Strate Limited 2006) 46.

${ }^{133}$ Strate Limited Bonds Handbook 46.

134 lbid. See also Bond Exchange of South Africa "BESA Milestones" http://www.bond exchange.co.za/besa/view/besa/en/page895?oid=629\&sn=Detail (accessed 2009-05-04); and Bond Exchange of South Africa "About BESA" http://www.bondexchange.co.za/besa/ view/besa/en/page65 (accessed 2009-05-04).

135 Bond Exchange of South Africa Overview http://www.bondexchange.co.za/besa/view/ besa/en/page108 (accessed 2009-05-04).

${ }^{136}$ Bond Traders' Association (hereinafter "the BTA").

137 Bond Traders' Association "Welcome to The Bond Traders' Association" http://www. bondtraders.co.za/bta/view/besa/en/page32 (accessed 2009-11-14). 
Association ${ }^{138}$ to represent the views and interests of the user firms registered to trade BESA-listed derivative instruments in $2008 .{ }^{1}$

BESA's annual turnover reached R13.8 trillion trades (USD1 971.3 billion) placing BESA's turnover fourth in the world after BME Spanish Exchange whose trades amounted to USD5 854, the London market at USD3 605 billion, followed by OMX at USD2 797 at the end of $2007 .{ }^{14}$

As the direct regulator of the bond market, BESA operates within the framework of the SSA and a set of rules and directives approved by the FSB.

\section{The consolidation of the JSE Limited and BESA}

The JSE announced that it had made a conditional offer to acquire the entire ordinary-share capital of the BESA on 27 October 2008. The deputy CEO of the JSE, Nicky Newton-King, stated that the proposed deal was "intended to create a world-class, unified multi-product exchange that efficiently provides sophisticated trading, clearing and settlement infrastructure to all its clients". ${ }^{14}$

The requisite majority of BESA Shareholders approved the proposed consolidation on 6 February 2009. ${ }^{142}$ This was followed by the unconditional approval from the Competition Tribunal on 3 June 2009. ${ }^{143}$ The High Court of South Africa sanctioned the consolidation on 9 June 2009 and BESA became a wholly-owned subsidiary of the JSE on 22 June 2009. ${ }^{144}$ The consolidation is believed to benefit both South Africa's interest-rate market, as it will enable a thorough and consultative process with all market participants to determine how best to promote the growth of South Africa's interest-rate market and South Africa's international competitiveness, by

${ }_{138}$ Derivatives Traders' Association (hereinafter "the DTA").

139 Bond Exchange of South Africa "Derivatives Traders' Association" http://www. bondexchange.co.za/besa/view/besa/en/page22265 (accessed 2009-11-14).

140 Bond Exchange of South Africa "Market performance 2007" http://www.bondexchange. co.za/besa/view/besa/en/page44712 (accessed 2009-06-21).

141 Arch "Announcement relating to a firm intention by the JSE Limited to make an offer for the ordinary shares in BESA" http://www.bondexchange.co.za/besa/action.media.download File?media_fileiOd=10597 (accessed 2009-05-19); and Cohen and Henry "JSE in bid to buy bond exchange" http://www.jse.co.za/docs.besa_deal/Media ReleaseFINAL.pdf (accessed 2009-04-29).

142 JSE Limited "Joint announcement by BESA and the JSE relating to the proposed scheme of arrangement between BESA and its shareholders" http://www.jse.co.za/docs/besa_deal/ BESA\%20JSE\%20Joint\%20Announcement\%20re\%20Scheme\%20Meeting\%20FINAL.pdf (accessed 2009-06-30).

${ }^{143}$ Bond Exchange of South Africa "BESA and the JSE welcome approval of merger by Competition authorities" http://www.bondexchange.co.za/besa/action/media/downloadFile? media_fileid=11490 (accessed 2009-06-30).

${ }^{144}$ Bond Exchange of South Africa "Joint announcement by BESA and the JSE relating to the sanctioning of the scheme of arrangement and the scheme of arrangement becoming unconditional" http://www.bondexchange.co.za/besa/action/media/downloadFile?media fileid=11510 (accessed 2009-06-30); and Bond Exchange of South Africa "BESA and the JSE welcome approval of merger by Competition authorities" http://www.bondexchange. co.za/besa/action/media/downloadFile?media_fileid=11490 (accessed 2009-06-30). 
leveraging the best each exchange has to offer to deepen the market, improve liquidity, create economies of scale and ultimately bring user costs down. ${ }^{145}$

Since the JSE and BESA are now operating as a single exchange, namely, the JSE, the legal framework pertaining to the JSE and BESA will have to be re-evaluated to determine whether both exchanges' regulatory frameworks should continue to exist in its current form or whether amendments will have to be made to consolidate some of these regulatory measures in order for the JSE to operate effectively and successfully. Until such time, Newton-King stated that "[l]isting requirements, membership requirements and trading, clearing, and settlement rules will remain unchanged".

\section{CONCLUSION}

This article has painted a picture of the regulatory environment in an effort to create an understanding of the financial markets to lawyers. Before one can embark on an in-depth analysis of the financial markets, it is necessary to disseminate information on the basic structure of the regulators and selected terminology, which was the objective with this article. It is hoped that more research will be done in this field by academics to create a rich base of literature for future legal scholars.

145 JSE Limited "Deal Overview" http://www.jse.co.za/besa-deal.jsp (accessed 2009-06-30); and JSE Limited "Offer to acquire BESA Shares" http://www.jse.co.za/Libraries/Investor_ Relations_Webcasts_and_Presentations/Offer_to_acquire_BESA_shares.sflb.ashx (accessed 2009-12-21).

146 JSE Limited "BESA and the JSE welcome approval of merger by Competition authorities" http://www.jse.co.za/docs/besa_deal/besa_20090603.pdf (accessed 2009-06-30). 